\title{
A Review Towards Theories, Concepts, Methods in International Relations, and Related International Legal Instruments for Conducting Research on Transnational Organized Crime
}

\author{
Iwan Sulistyo \\ International Relation Department \\ Lampung University \\ Lampung, Indonesia \\ iwan.sulistyo@fisip.unila.ac.id
}

\author{
Indra Jaya Wiranata \\ International Relation Department \\ Lampung University \\ Lampung, Indonesia \\ indrajayawiranata@gmail.com
}

\author{
Suci Indah Lestari \\ International Relation Department \\ Lampung University \\ Lampung, Indonesia \\ suciindah122@gamil.com
}

\begin{abstract}
Although viewed as an ambitious duty, this preliminary work will identify various theories, concepts, and methods in the study of International Relations (IR) and various instruments related to international law for conducting research on Transnational Organized Crimes (TOC). This effort relies on the experts' awareness that main theories within the IR literature are not yet fully available in comprehensively supporting analysis on TOC. Numerous recent references reveal that TOC is one of the prominent issues which has extensively emerged. TOC has also seriously been a threat to human security, particularly after the end of the Cold War (post-1990) until now. Therefore, methodologically, the writers did this work by collecting various latest references and archives within the discipline of IR, including conventions and protocols referred to TOC issues. All contents were critically reviewed and linked to the context of analyzing TOC. This work will help researchers and scholars quickly find the relevant analytical framework so that their analysis becomes more comprehensive than before. The writers realize that this article was merely limited to reviewing particular parts. There is indeed still a need for further projects to collect the remaining dimensions.
\end{abstract}

Keywords-Theories, Concepts, Methods, International Relations, Conventions, Protocols, Transnational Organized Crime

\section{INTRODUCTION}

Being a discipline within the social sciences and a branch of political science, International Relations (IR) has constantly been developing, at least since the end of World War II. Put simply; it studies relations among actors of both states and non-states [1]. After the Cold War, especially in the early 1990s, significant changes were happening globally, particularly in the milieu of international politics, namely the collapse of the Soviet Union and nation-states became economically interconnected. These events eventually impact reality regarding so-called global politics, where the interaction among state and non-state actors becomes increasingly intense.

As a result, the focus of IR as an academic discipline is no longer only on the ideological, military, and nuclear rivalry between the two great powers and their alliances. Still, it has also primarily expanded to various other issues. Globalization becomes the key term to describe that dynamic - a complicated process that involves multiple aspects of life connecting and exchanging economy, culture, politics, and technology [2].

Supported by globalization, one of the substantial issues or trends in IR is transnational organized crime (TOC). It is seen as one of the various non-traditional threats that exist within IR studies. The post-Cold War period has allowed the scale and scope of transnational criminal activity to become increasingly widespread, mainly because it is underpinned by the latest state-ofthe-art technology and international communications [3].

TOC itself has diverse types that, over time, continuously flourish. The United Nations Office on Drugs and Crimes (UNODC) states that global crimes and numerous transnational organized crimes are linked to the cyber platform. It covers trafficking in person, firearms, corruption, drug trafficking, fraudulent medicines, smuggling of migrants, money 
laundering, maritime piracy, terrorist issues, forest and wildlife crimes, and crime [4].

Specific variants of transnational crime do not stand alone. It is certainly also connected to other types. For example, cybercrimes may be related to terrorism or to money laundering that certain organized-crime groups manage. Whatever the combination, the losses incurred from these various types of transnational crimes are not small. Several scholars in contemporary IR admit that the main established theories do not fully offer analytical frameworks for studying the problems of TOC. Viotti \& Kauppi [5] recognize the lack of IR theories in providing a theoretical landscape to explain TOC. By realizing that, while realists accentuate their outlook on states' security and potential military threat of invasion from other states, liberals accentuate economic institutions, NGOs, and non-state actors' role in encouraging cooperation among states. To add more, though not explicitly expressed, Peterson [6] puts their attention to the challenges of liberal and neoliberal approaches in engaging what he called stabilizing social conditions and problems.

Yuliya Zabyelina, a prominent and productive scholar concerned about studying TOC, also confirms that the main predicament in IR theories appears when TOC issues need to be explored. Although acknowledging the weaknesses of some major IR theories for analyzing TOC, she reveals that some other theories possess the performance to do so [7].

Several references found, almost all directly ask the roles, responses, and responsibility of a sovereign state (and government), the international community or world society to transnational criminal activities, notably organized criminal gangs and mafias. It ultimately, at least, comes from Strange [8] through questioning the shift of the government's policies and attitude, specifically the Italian government, in tackling drugs and illicit global trades. Aspects of states' power and legitimacy in facing the TOC also become part of attention seen by Campbell, MacKinnon, \& Stevens [9].

In sum, the analytical frameworks provided by IR have not been provided and are even seen as incomplete works. Therefore, it is academically necessary and exciting to critically observe theories, concepts, and methods in the study of IR (and international legal tools), which are valuable and relevant to conducting research on TOC. Therefore, this article will review various theories, concepts, and methods in the study of IR to support research in the context of TOC, including its international legal instruments. In other words, this research tries to answer two questions: How does the study of IR provide its theories, concepts, and methods for researching TOC; and, what are international legal instruments relevant to it? Knowing these things will contribute to the development of social sciences, both in multi, inter-, and cross-disciplinary fields, especially in IR, political science, and international law.

\section{DEFINITION}

This part will explain several key terms: theory, concept, method, and international legal instrument. Before giving those various meanings, placing TOC in its appropriate context is also essential here.

TOC is heavily placed into international security, precisely non-traditional issues because it is not related to strategic studies or traditional security. Consequently, it deals with both state and non-state actors with the broadest sense of spectrum. It is also possible to engage with other related disciplines within social sciences like Criminology, International Law, Criminal Law, Sociology and Anthropology. It is also imperative to carefully note that, for some cases, the critical words of both transnational crimes and global crimes - but not international crimes - can be interchangeably used for finding references and data.

TOC is a harmful action organized by a group of people across national borders and uses sophisticated technology intending to gain profits for the perpetrators of the crime. The term transnational underscores the international aspect that implies organized criminal squads operating outside of the countries' boundaries, forming a criminal system and are interconnected [10].

Based on "the United Nations Convention Against Transnational Organized Crime" (UNCTOC), an organized criminal group is a composed group consisting of three or more individuals. They commit single or more dangerous crimes or offences, directly or indirectly, earning financial or other material profits (see Article 2). To add more, organized crime is part of cross-border with several conditions: committing in more than one country; committing in one country but planning in another: committing in one country but involving a criminal group connected to crime in another country. The last one is done in one country but has implications in other countries (see Article 3) [11].

Move to the following term, theory. In simple terms, it is seen as a scientific explanation of certain phenomena (in this case, social phenomenon, namely TOC). More specifically, Viotti \& Kauppi [12] explain the theory as "an intellectual construct that helps us explain or predict what we observe - interpreting facts and identifying regularities and recurrences or repetitions of observed phenomena". In other words, theory helps us scientifically understand the world because it contains relationships among variables, regarding explanations of theories and other concepts that are close together in the general context of social science [13].

Now, what is a concept? According to Hague, Harrop, \& MacCormick [14], a concept reflects an 
idea, a specific term, or a particular category containing a definition restricted to attributes that go with it. They even distinguish the definition between concept and conception by arguing that it eventually bears a conception when a concept is understood with view or interpretation. In another narration, they explain, a conception refers to how something is understood or interpreted.

In addition to that, research methods underpin particular techniques consisting of tools and how researchers collect, sort, and analyze information and data to gain conclusions. In that sense, those who use methods have the responsibility to reassure that their inference is valid and methodologically reasonable [15].

Lastly, international legal instrumentsreviewed in this study cover specific international conventions and protocols usually associated with international law, referring to Heywood [16], understood as "a set of compulsory and enforceable rules" that reflect the will of extraordinary power. Some actors/scientists reject the idea of international law because there is no central authority in international politics that can consistently enforce the existing rules.

\section{THEORIES AND CONCEPTS IN IR}

After giving definitions for each term, at this point, a question then arises: How do we differentiate whether it is a theory or a concept within IR literature? Chatterjee [17], in his book, at least helps us by referring to four important theoretical schools of thought in IR: realism, liberalism, theories that are founded on a global society perspective, and theories that rely on international political economy [18].

Realism emphasizing war and power politics among states supplies inappropriate linkages to exploring TOC. Now, let us look at the fundamental assumptions in liberal, neoliberal, and pluralist theories. By synthesizing these views, there is a gap to generally contemplate competitive interaction and interdependence among state and non-state institutions, including groups and individuals' free will. Particularly free-market economy supported by progressive technologies could bear possible harmful activities within the context of globalization. In other words, while avoiding war and conflict, global crime will simultaneously ride to that sense; moreover, when institutional/formal perpetrators are involved. In comparison, both armed conflicts and global/transnational crime are destructive for human beings. This proposition is possibly debatable or even out of context, yet it is perhaps part of providing critics for them when we consider peace and social order.

Aside from theories, Chatterjee [19] explores particular IR concepts in his chapter as well, just mentioning relevant, covering national interest, foreign policy, diplomacy, non-state actors (intergovernmental organization and international non- governmental organization). In addition to the listed concepts, several scholars like (Heywood), (Diez, Bode, \& da Costa), and (Griffiths, O'Callaghan, \& Roach) also provide numerous concepts on their books that undoubtedly useful for us to consider the list [2022].

Further, for this initial research, researchers use their common sense in selecting theories and concepts randomly. In other words, for the time being, writers' knowledge, intellectual experience, and scholarly perception became the cornerstone of choosing specific theories and concepts containing enough elements to support this research. It is pointedly reasonable because IR theories and concepts reside in the broadest picture. Selected IR theories and concepts will be reviewed as followed.

\section{A. National Interest}

The governments have the authority to formally act and enforce the laws, even by using force.

\section{B. Foreign Policy}

Being a relatively old concept and theory, in general understanding, foreign policy expresses a country's national interest toward an external formal entity with sovereignty. It has vast areas where TOC could also certainly take place, not just for particular global issues relating preliminary to cultural, conflicts, trade, military, developmental, or other conventional ones. It is essential to emphasize that the formulation and implementation of foreign policies related to TOC should consider efforts to protect the potential of the state's financial losses and citizens' security and the next generation in a nation-state.

In term of formulating foreign policy, it is initially necessary to respectfully borrow Waltz's thoughts, particularly at the individual and nation-state level. Although he puts the emphasis on the causes of war, that particular notion is still relevant in explaining TOC. In addition to that, due to the importance of decisionmaking theories here, several models are worthwhile; it covers rational actor, incremental, bureaucratic organization, and cognitive processesandbelief-system. The first aspect will help analyst to carefully explain specific considerations chosen by the president, prime minister, or related ministers and politician in parliament to decide any mean to deal with TOC. Using incremental model could support scholar to reveal the dynamic of environment that affects the decision is made which needs adjusting several dimensions. Next, bureaucratic organization account for the consequences of the decision. Last, cognitive processesandbeliefsystem stresses the policy makers' circumspection and their selective behavior in screening information to take decision. Thus, by using these aspects simultaneously could contribute to the strength of analysis in providing comprehension on foreign policy making mechanism associated with TOC [23] [24]. 
While philosophical sense of foreign policy and IR theory are, for instance, analysed by Chernoff [25] with elaborating its scientific means, Jackson \& Sørensen [26] complement the previous models above by supplying another two approaches which are multidimensional and constructivist. The former involves diverse of theories in IR; while the later involves the ideas, discourse, and identity within intersubjective world. The last two notions are possibly the interesting to support research on TOC in the spectrum of foreign policy.

A notion that must be highlighted is that the analytical frameworks on foreign policy coresponded to TOC should be placed in a wider neoteric circumtances of nonmilitary dimension, not based merely on historical context that is influenced much more by conflict and war between and among nations in political arena.

\section{Diplomacy}

In this sense, diplomacy is viewed as a term associated with the art of formally and informally political complex communicating and negotiating. In this particular context, the TOC issues are both potential and existential threats faced by nation-states. The states' national interests and objectives rely on communicative and negotiated mechanisms as well.

Numerous concepts in the area of diplomacy could contribute to explain TOC interestingly. It lies in public diplomacy to contemporary digital diplomacy. Nevertheless, the writers of this article suggest that using multitrack diplomacy could be useful and beneficial since it gives a broader predominance view with diverse elements, levels of analysis, and actors involved in order to underpin research on TOC. Moreover, this suggestion relies primarily on the prominent characteristic of TOC itself which is heavily complex so that it certainly needs a comprehensive approach, not just relying on a particular outlook.

A reference on multitrack diplomacy written by Diamond [27] provides a tremendous framework for analysis covering at least nine tracks. The diverse tracks cover diplomacy proceeded by: government, nongoverment, private sector, indivividual citizen; research, training, and education; advocacy, religious way, funding, and mass media. Although its emhapasis is on peacemaking, that particular literature is also interrelated to TOC issues for certain relevant tracks. The spirit of multitrack diplomacy in this sense is the same, its is to gain a peaceful world without much potential security threats, particularly from non military.

Through formal means, government among nationstates together with international organizations play their fundamental roles in finding alternative solutions to TOC. Thus, convincing each other by diplomatic approach becomes the key element though it will probably be seen as an exclussive way because of its formal aspects. In addition the that, non governmental or professional entities could be an alternative to support the effort in overcoming problems of TOC in heterogeneous nation-states, focusing on numerous creative solutions by doing workshop and other academic activities, including measures related to capacity building of official apparatus and vulnarable society or the public at large. The roles of business or private sector goes to how to, together with government, strenghten the economic aspect of the people so that they become prosperous and potential threats linked to victims of TOC could be early anticipated; close to poverty will be a risky for vulnarables groups. Beside that, while private citizens with their informal community have concerns on solving TOC problems by following the dynamic on the ground level and also the internet in a broadest spectrum, adovocacy can be handled by activists. Therfore, campaign in war againts TOC in all its forms is inevitable. We shouls also take into account the exixtance of mass media dealing with information to shape a perception for the society, specifically to make public aware. Public, in this particular sense, is nationwide.

\section{International Organization and Global Governance}

TOC is diverse activities with extremely dangerous consequences done by mostly non state actors. Thus, any authoritative effort should totally be involved. Even though this term is initially associated with economic dimension, it has expanded meaning to other sectors, including TOC. The focus will be on how the problems and related global and regional institutions are carefully managed and maintained where partnership and network become basically important. In managing the issues, agents in global governance cover both states and nonstate actors.

If we look at the basic understanding of concept itself, global governance means the importance of making common decision taking int account the institutions and regulations at global level in response to particular world problems [28]. Two specifically prominent literatures elaborating about TOC relative to global governance and institutions should be viewed. Both are written by the same single writer, Anja P. Jakobi, entitled Common Goods and Evils? The Formation of Global Crime Governance [29] and Crime, Security and Global Politics: An Introduction to Global Crime Governance [30]. The former explains the historical aspect of forming global crime governance (GCG) for particular kinds of TOC. It also provides lenses on GCG consisting of its patterns and strategies, including the roles of nonstates actors. The perspectives provided will help to broaden the focus of research on TOC linked to global governane, involving institutions and policies flourished and adopted in all layers, not just relying on usual global governance theories which deal heavily with economic milieu. Meanwhile, the later points out the international ties 
facing crimes, supported by particular specific isses on TOC with their dynamic and perspectives to observe each form. However, it is lack of giving case studies in several regions and countries since it only for analysing issues in the US.

\section{E. Securitization}

Using the concept of securitization to analyze TOC is also convenient and impressive because it offers relatively complete elements. The leading scholars regarding securitization that should be undoubtedly referred to Buzan, Wæver, \& Wilde, with one of their magnum opuses, Security: A New Framework for Analysis [31]. TOC itself, with its heterogeneous forms, could be seen as part of nonmilitary threat. Thus, referring to their categories, the scope related to TOC will of course be on environmental, economic, societal, including also political side which all are obviously existential threats. Using the elements of securitizing actors (the actors that do securitization), speech act (the actor's actions in the context of securitization), referent object (entities that will be threatened by the existence of the issue if it is not taken seriously), and audience (the parties trying to be influenced by the actors to believe in the existence of existential threats) could be existing at the national, regional, or global level. In this sense, we assume that actors consist of both state and nonstate entities. Nevertheless, though this concept has unique elements, it is also necessary to limit the scope when analyzing the case.

\section{F. Human Security}

Organized crime and terrorism are increasingly being viewed by the international community as direct dangers to national and international security, which they are, rather than as issues of human security and human rights. National security goals have a propensity to take precedence above concerns about personal security. Some important human security and human rights concerns were overlooked in the process. Claims that public safety or national security are in jeopardy foster a disaster mentality, as is typical of moral panics; fear and worry about crime and terrorism can be used by governments to restrict people's rights, particularly the rights of minorities and foreigners [32]. Many minority groups felt under attack in their own country after September 11, 2001.

Human trafficking is one of the fastest-growing types of international crime. Many citizens have been vulnerable to human traffickers as they seek a better life away from their current circumstances as a result of many countries' neglect of human security. The availability of people to be trafficked has been aided by the internationalization of corruption, the growth of regional wars since the end of the Cold War, and the advent of globalization, which has widened the economic divide between affluent and poor. At the same time, heightened penalties and prosecutions for drug traffickers have made it an appealing option for many transnational criminals [33].

\section{G. International Cooperation}

Deepening and broadening bilateral, multilateral, regional, and international cooperation among actors is a must for combating TOC. Through migration, increased mobility, and the transformation in information and communication technology, globalization of both economic and social links has provided unparalleled potential for TOC. Establishing and maintaining cross-border criminal relationships, committing predatory crimes across longer distances, and engaging in certain unlawful activities on the Internet, such as fraud and illegal gambling, have all become significantly easier [34]. We must not, however, exaggerate the impact of globalization on the criminal world. It is illogical for a foreign criminal organization to try to put established local criminal "community" out of business.

In actuality, cooperating with local criminals and forming joint businesses with them, rather than competing with them, remains a critical component of success. Under the influence of globalization, organized crime appears to have become more transnational, yet it has not lost its substantial social foundations in local settings [35]. International collaboration is undoubtedly necessary in the fight against TOC, but the struggle should remain framed largely as a domestic law enforcement matter requiring a coordinated response, rather than as an external or global danger to national security.

\section{Method to Under Pin the RESEARCH ON TOC}

Chatterjee [36] highlights four principal methodologies in IR. They are: traditional/classical that considers normative dimensions like historical, philosophical, and legal/moral where, of course, history, political science, and philosophy are relevant here; behavioural, which relies on scientific ways to verify hypothesis; positivist that inherit behavioralism in the current mode that utilizes statistical or mathematical analysis to prove the empirical and logical thought; and post-positivist which has the broadest spectrum. In inquiring about TOC within IR, we argue that all of the methodologies are possible since we, the writers, adhere to the definition that enables us to look into the broadest sense, both for actors and issues.

By understanding IR is "a branch of social science is concerned with relations among nations, and other issues like non-state actors, international political economy, international security, foreign policies of major powers, globalization, international terrorism, international environment, and area studies" [37], we would have overwhelming scope to observe in the context of IR discipline.

We should pay much attention to the validity and reliability of the data collected since research on TOC is associated with the dark side of globalization and the negative area of life. In addition to methods, we should 
also consider the variety of levels of analysis in IR as Kauppi \& Viotti [38] whether individual, group, national, international/global. By deciding it, we could be able to analyze the issues appropriately. Another crucial aspect that should be underlined here is research ethics.

\section{INTERNATIONAL LEGAL INSTRUMENTS}

The fact of the real threat of transnational organized crime/TOC at this time strengthens the recognition of TOC as a common problem by countries in the world. So international cooperation is needed in the settlement which has been regulated in a series of mutually agreed provisions as an instrument of international law enforcement. As the main objective of UNCTOC is to encourage cooperation directed at efforts to prevent and eradicate transnational organized crime (see Article 1) [39]. The Convention and its protocols include setting standards for the domestic law of each state party and co-operation guidelines for more comprehensive action on each type of transnational organized crime. According to UNODC, TOC activities are related to illegal drugs, global crime, and various crimes, namely trafficking in persons and organs, firearms, corruption, drug trafficking, counterfeit drugs, migrant smuggling, money laundering, maritime piracy, terrorist issues, intellectual property theft, artistic and cultural objects, endangered species of flora and fauna, and crimes related to cyber platforms [40].

UNCTOC enables states parties to commit to mutual assistance, which includes international cooperation in the form of seizure of evidence and proceeds of crime (see Article 13), acceleration and expansion of extradition gains (see Article 16), legal assistance (see Article 18), and cooperation in the investigation of the suspect (see Article 19 and Article 20). Including other special actions such as exchanging information, and complying with bilateral and multilateral agreements in the context of international law enforcement as regulated in articles 26 and 27. Article 30 of this convention is also contained in the coordination of countries with one another in the form of assistance in technical matters and resources [41]. States parties should consider adopting the preventive measures in article 31 and its protocols which specifically add to the scope of the main criminal problem.

In the fight against money laundering crimes, based on article 7 of UNCTOC, each state party considers the establishment of a financial intelligence unit as a facility for collecting and disseminating information at domestic and international levels on potential crimes [42]. Similar steps are also regulated in article 14 of the United Nations Convention Against Corruption/UNCAC. Continued in the next article, this convention regulates the coordination of the settlement of acts of corruption through legislative steps involving foreign public officials, or a person or entity who gains unofficial benefits from the conduct of international business (see Article 8) [43]. Furthermore, the main problem of corruption is discussed specifically in UNCAC which encourages countries to carry out international cooperation following articles 44 to 50 of this convention (see article 43), and collaborate with regional and international organizations, or participate in international programs (see Article 5) [44].

The crime of international theft is also included in the TOC category, namely the theft of intellectual property, as well as art and cultural objects. Intellectual property regulations in these countries have been regulated in the Trade Related Aspects of Intellectual Property Rights/TRIPS [45] agreement which refers to the Berne Convention for the Protection of Literary and Artistic Works [46] and the Convention Establishing the World Intellectual Property Organization [47]. In particular, to suppress international trade that violates intellectual property rights, each member country conducts international cooperation and facilitates the provisions of the assistance agreement including the promotion of cooperation and technical support such as the exchange of information in trade administrations that goods are considered suspicious, counterfeit, and pirated copyrighted goods (see Article 67 and Article 69) [48].

The three protocols that follow UNCTOC are complementary to achieving the convention's objectives in resolving the specific scope of transnational organized crime problems. First, the Protocol to Prevent, Suppress and Punish Trafficking in Persons, Especially Women and Children, includes an international approach in combating the crime of trafficking in persons. Based on article 8 of this protocol, countries are asked to help each other and prioritize the safety aspect of the victims of trafficking in persons as well as their internationally recognized human rights, so as not to hinder the process of identifying or permitting the return of victims [49]. Efforts are shown through border control (see Article 11), exchange of information (see Article 10), and strengthening bilateral and multilateral cooperation in the education, social and cultural fields to suppress the factors causing the crime of human trafficking (see Article 9). Several other international instruments relevant to these crimes are the Universal Declaration of Human Rights [50], "the Convention for the Suppression of the Traffic in Persons and the Exploitation of the Prostitution of the Others" [51], Convention on the Rights of the Child [52], and the Optional Protocol to the Convention on the Rights of the Child Concerning the Sale of Children, Child Prostitution and Child Pornography [53].

Second, the Protocol against the Smuggling of Migrants by Land, Sea, and Air against the threat of criminal smuggling of migrants which is increasing along with the trend of migration. Article 7 of this protocol states that states parties are obliged to cooperate to prevent and follow up crimes, especially 
the smuggling of migrants from marine areas [54]. The cooperation stipulated in this protocol is the activity of maintaining communication between the border control agencies of the states parties (see Article 11), joint military training activities (see article 14), providing mutual protection assistance to migrants (see Article 16), and preventive measures others (see chapter 15). States may also consider cooperating with international organizations in the process of repatriating victims of smuggling migrants (see Article 18).

The last one is the Protocol against the Illicit Manufacturing of and Trafficking in Firearms, Their Parts and Components, and Ammunition. In the context of international relations, the crime of manufacture and illicit trade in firearms is related to international trade activities between countries. For this reason, article 10 of this protocol stipulates several provisions in the process of export and import of weapons by state parties, which are principally the goods certification authority [55]. This is important as a marker of the legality of weapons to increase the effectiveness of security (see article 8), considering that increasingly advanced technological developments also encourage opportunities for the creation of new illegal weapons. So that the state parties need to strengthen bilateral, regional, and global cooperation and with relevant international organizations on the manufacture and illicit trade of firearms under articles 13 and 14 of the protocol. This main issue was discussed by hundreds of countries at the United Nations Conference on the Illicit Trade in Small Arms and Light Weapons in All Its Aspects.

Moreover, it is disappointing in the evolving relationship between the TOC and terrorist crimes that prompted the adoption of three comprehensive international conventions under the Ad Hoc Committee [56]. First, the International Convention for the Suppression of Terrorist Bombings seeks to condition countries to look at each other in preventing terrorist activities that are identical to the use of explosive devices (article 15), and in court proceedings requiring extradition on both sides according to article 13 [57]. Then, the International Convention for the Suppression of the Financing of Terrorism has become a successful anti-terrorism agreement in the world which contains preventive measures for state parties to monitor and detect transportation across physical capital boundaries as well as supporting instruments as a supporting tool. criminal activities (see Article 18) [58]. The final treaty text is the International Convention for the Suppression of Acts of Nuclear Terrorism, article 7 and article 18 of this convention encourage cooperation in assistance, especially between countries that have radioactive and nuclear materials, and relevant international organizations to take preventive and preparation actions against terrorists [59].

In its development, acts of terrorism are increasingly related to illicit trade and drug abuse. This problem has attracted the attention of countries in the world as an international crime capable of becoming a source of war and killing many lives on an unprecedented scale. It is regulated in the United Nations Convention Against Illicit Traffic in Narcotic Drugs and Psychotropic Substances that every crime in this convention can be extradited through an agreement between the states parties (see Article 6) which cooperate to provide mutual legal assistance (see Article 7), conducting investigations and suppressing the intensity of crime by establishing special training programs (see Article 9) [60]. Even article 10 of this agreement contains cooperation and the provision of international assistance directly or through international organizations to transit countries to strengthen traffic control of illicit trade in narcotics and psychotropic drugs. In addition, each state party needs to participate in building a system for monitoring the movement of these prohibited goods in free trade areas and free ports (see Article 17 and Article 18) [61].

Some transnational crimes that involve the sea as a transportation route - such as human trafficking, illegal drugs, illicit trade in firearms, people smuggling, and sea piracy - enforcement rules by countries in the sea area regarding jurisdictional issues will refer to the United Nations. Nations Convention on the Law of the Sea/UNCLOS [62]. However, the rules for authorizing and cooperating with countries in combating maritime piracy crimes can exclusively be adopted from the Protocol for the Suppression of Unlawful Acts Against the Safety of Fixed Platforms Located on the Continental Shelf 1988/SUA PROT [63] With this, transnational crimes have had both direct and indirect effects involving more than one country. The more diverse and developing forms of transnational crime, the more there will be renewal and the formation of new agreements at the bilateral, multilateral, and joint levels with international organizations. Therefore, this shows how important international legal instruments are in analyzing TOC research, especially in the study of international relations.

\section{CONCLUSION}

This project is curious about inquiring about the availability of IR theories, concepts, and methods and the formal international legal basis to underpin research on TOC. The scarcity of matters within IR has encouraged the writers to do so. Understanding TOC is extremely important in formulating policies and strategies by national and global governments to counter it. By doing so, we would deliberately anticipate the noxiousness coming from those global criminal activities. This research does not ambitiously reach all theories, concepts, and methods in IR. Having investigated the particular main elements in IR, the writers realize that many of them need to be evaluated in the following projects, paying much attention to exploring the post-positivism of IR theories. Besides 
things that have been reviewed, it requires alternative methods to be studied hereafter as well.

\section{REFERENCES}

[1] See, for instance, Sutch, P., \& Elias, J. (2007). International Relations: the Basics (pp. 1-2). New York: Routledge.

[2] Campbell, P. J., MacKinnon, A., \& Stevens, C. R. (2010). An Introduction to Global Studies (p. 4). Chichester: WileyBlackwell.

[3] Viotti, P. R., \& Kauppi, M. V. (2013). International Relations and World Politics (p. 360). New York: Pearson.

[4] See UNODC. (2021, July 1). Retrieved from United Nations Office on Drugs and Crime: https://www.unodc.org/unodc/index.html.

[5] Viotti, P. R., \& Kauppi, M. V. (2013). International Relations and World Politics (p. 359). New York: Pearson.

[6] Peterson, V. (2014). How is the world organized economically? In J. Edkins, \& M. Zehfuss, Global Politics: a New Introduction, Vol. 2, (p. 374). New York: Routledge.

[7] Zabyelina, Y. (2009, May). Transnational Organized Crime in International Relations. Central European Journal of International and Security Studies (CEJISS), 3(1), 9-19.

[8] Strange, S. (1996). The Retreat of the State: the Diffusion of Power in the World Economy (p. 114). New York: Cambridge University Press.

[9] Campbell, P. J., MacKinnon, A., \& Stevens, C. R. (2010). An Introduction to Global Studies (p. 47). Chichester: WileyBlackwell.

[10] Đorđević, S. (2009, April-June). Understanding Transnational Organized Crime as a Security Threat and Security Theories. Western Balkans Security Observer, 4:13, 39-52.

[11] UNODC. (2004). The United Nations Convention against Transnational Organized Crime ( $\mathrm{p}_{\mathrm{d}}$ 5). Retrieved from https://www.unodc.org/documents/middleeastandnorthafrica/ organised-

crime/UNITED_NATIONS_CONVENTION_AGAINST_TR ANSNATIONAT_ ORGANIZED_CRIME_AND_THE_PRO TOCOLS_THERETTO.pdf

[12] Viotti, P. R. \& Kauppi, M. V. (2013). International Relations and World Politics (p. 26). New York: Pearson.

[13] See also the explanation Hunt, E. F., \& Colander, D. C. (2017). Social Science: an Introduction to the Study of Society. New York: Routledge.

[14] Hague, R., Harrop, M., \& MacCormick, J. (2016). Political Science: A Comparative Introduction (p. 2). New York: Palgrave MacMillan.

[15] Walliman, N. (2011). Research Methods: the Basics (p. 7). New York: Routledge.

[16] Heywood, A. (2011). Global Politics (p. 331). New York: Palgrave

[17] Chatterjee, A. (2010). International Relations Today: Concepts and Applications (p. 4). New Delhi: Pearson

[18] See also Dunne, T., Kurki, M., \& Smith, S. (2013). International Relations Theories: Discipline and Diversity. Oxford : Oxford University Press.

[19] Chatterjee, A. (2010). International Relations Today: Concepts and Applications. New Delhi: Pearson.

[20] Heywood, A. (2015). Key Concepts in Politics and International Relations. London: Palgrave.

[21] Diez, T., Bode, I., \& da Costa, A. F. (2011). Key Concepts in International Relations. London: Sage Publications.

[22] Griffiths, M., O'Callaghan, T., \& Roach, S. C. (2008) International Relations: The Key Concepts. New York: Routledge.

[23] Heywood, A. (2011). Global Politics (pp. 129-134). New York: Palgrave.

[24] Brown, C. \& Ainley, K. (2005). Understanding International Relations (pp. 63-79). New York: Palgrave MacMillan.

[25] Chernoff, F. (2005). The Power of International Theory: Reforging the Link to Foreign Policy-Making through Scientific Enquiry. New York: Routledge.

[26] Jackson, R., \& Sørensen, G. (2013). Introduction to International Relations: Theories and Approaches. Oxford : International Relations:
Oxford University Press.

[27] Diamond, L. (1996). Multi-Track Diplomacy: A Systems Approach to Peace. West Hartford: Kumarian Press.

[28] Sinclair, T. J. (2012). Cambridge: Polity Press.

[29] Jakobi, A. P. (2013). Common Goods and Evils? The Formation of Global Crime Governance. New York: Oxford University Press.
[30] Jakobi, A. P. (2020). Crime, Security and Global Politics: An Introduction to Global Crime Governance. London: Red Globe Press.

[31] Buzan, B., Wæver, O., \& Wilde, J. d. (1998). Security: A New Framework for Analysis. London: Lynne Rienner.

[32] Dandurand, Y., \& Chin, V. (2011). Human security objectives and the fight against transnational organized crime and terrorism. In S. Okubo, \& L. Shelley, Human security, transnational crime, and human trafficking : Asian and Western perspectives (pp. 38-136). Oxon: Routledge.

[33] Shelley, L. (2011). International trafficking An important component of transnational crime. In S. Okubo, \& L. Shelley, Human security, transnational crime, and human trafficking : Asian and Western perspectives (pp. 135-136). Oxon: Routledge.

[34] Albanese, J. S., \& Reichel, P. L. (2014). Transnational organized crime : an overview from six continents. USA: SAGE.

[35] Hobbs, D. (1998). Going down the glocal: The local context of organized crime. Howard Journal, 37(4), 407-422.

[36] Chatterjee, A. (2010). International Relations Today: Concepts and Applications (p. 4). New Delhi: Pearson.

[37] Chatterjee, A. (2010). International Relations Today: Concepts and Applications (p. 5). New Delhi: Pearson.

[38] Kauppi, M. V., \& Viotti, P. R. (2020). International Relations Theory (pp. 8-11). London: Rowman \& Littlefield.

[39] UNODC. (2004). The United Nations Convention against Transnational Organized Crime (p. 5)

[40] UNODC. (2004). The United Nations Convention against Transnational Organized Crime (p. 2).

[41] UNODC. (2004). The United Nations Convention against Transnational Organized Crime (p. 32).

[42] UNODC. (2004). The United Nations Convention against Transnational Organized Crime (p. 9).

[43] UNODC. (2004). The United Nations Convention against Transnational Organized Crime (p. 10).

[44] UNODC. (2004). United Nations Convention against Corruption. Retrieved July 4, 2021, from United Nations Office on Drugs and Crime:

[45] WTO. (1994). TRIPS - Trade-Related Aspects of Intellectual Property Rights (p. 321). Retrieved July 4, 2021, from World Trade
https: $: /$ www.google.com/url?sa=t\&rct=j\&q=\&esrc=s\&source $=$ web \&cd $=\& \mathrm{cad}=\mathrm{rja} \& u a c t=8 \& \mathrm{ved}=2$ ahUKEwi2 $\mathrm{p}$ yUv8fy Ah UTcCsKHYVvAssQFnoECBAQAQ\&url=https $\% 3$ A $\% 2 \mathrm{~F} \% 2$ Fwww.wto.org\%2Fenglish\%2Fdocs e\%2Flegal e\%2F27trips.pdf\&usg=AOvVaw01BSSuMuNVRFMLM5q9ynRD

[46] WIPO. (1971). Berne Convention for the Protection of Literary and Artistic Works. Retrieved July 4, 2021, from World and Artistic Works. Retrieved uly 4, 2021, from World
Intellectual https://www.wipo.int/treaties/en/ip/berne/

[47] WIPO. (1967). Convention Establishing the World Intellectual Property Organization. Retrieved July 4, 2021, from Wolrd Intellectual Organization: https://www.wipo.int/treaties/en/convention/

[48] WTO. (1994). TRIPS - Trade-Related Aspects of Intellectual Property Rights (pp. 348-349).

[49] UNODC. (2004). The United Nations Convention against Transnational Organized Crime (p. 45).

[50] OHCHR. (1966-2021). International Covenant on Civil and Political Rights. Retrieved July 4, 2021, from OHCHR:
https://www.ohchr.org/en/professionalinterest/pages/ccpr.asp $\mathrm{x}$

[51] OHCHR. (1949). Convention for the Suppression of the Traffic in Persons. Retrieved July 4, 2021, from OHCiR: ersons.aspx

[52] OHCHR. (1989). Convention on the Rights of the Child. Retrieved July 12, 2021, from OHCHR: https://www.ohchr.org/en/professionalinterest/pages/crc.aspx

[53] OHCHR. (2000). Optional Protocol to the Convention on the https://www.ohchr.org/en/professionalinterest/pages/opsccrc.a spx

[54] UNODC. (2004). The United Nations Convention against Transnational Organized Crime (p. 56).

[55] UNODC. (2004). The United Nations Convention against Transnational Organized Crime (p. 76).

[56] UN. (2021). Ad Hoc Committee established by General Assembly resolution 51/210 of 17 December 1996. Retrieved Augustus 19, 2021, from Ad Hoc and Special Committees: https://legal.un.org/committees/terrorism/

[57] UN. (1997). The International Convention for the Suppression of Terrorist Bombings (pp. 10-11). Retrieved Augustus 19, 
2021,

from

UNTC:

https://treaties.un.org/Pages/ViewDetails.aspx?src=TREATY \&mtdsg_no=XVIII-9\&chapter $=18 \&$ clang=_en

[58] UN. (1999). The International Convention for the Suppression of the Financing of Terrorism (pp. 10-12). Retrieved July 4 2021, from https://treaties.un.org/pages/ViewDetails.aspx?

[59] UN. (2005). The International Convention for the Suppression of Acts of Nuclear Terrorism (pp. 5-12). Retrieved Augustus 19, 2021, , UNTC: https://treaties.un.org

$15 \&$ chapter $=18 \&$ Temp $=$ mtdsg $3 \&$ clang $=$

[60] UNODC. (1988). United Nations Convention against Illicit Traffic in Narcotic Drugs and Psychotropic Substances, 1988 (pp. 7-11). Retrieved July 4, 2021, from United Nations Office on Drugs https://www.unodc.org/unodc/en/treaties/illicittrafficking.html?ref=menuside
[61] UNODC. (1988). United Nations Convention against Illicit Traffic in Narcotic Drugs and Psychotropic Substances, 1988 (pp. 15-16).

[62] UN. (1982). United Nations Convention on the Law of the Sea of 10 December 1982. Retrieved July 4, 2021, from United hattps://www.un.org/depts/los/convention_agreements/convent ion_overview_convention.htm

[63] IMO. (2005). International Conference on the Suppression of Unlawful Acts against the Safety of Maritime Navigation (SUA): Retrieved July 13, 2021, from Internatonal Maritime Organization:

https://www.imo.org/en/KnowledgeCentre/ConferencesMeeti ngs/Pages/SUA.aspx

[64] UN. (1976). Convention on International Trade in Endangered Species of Wild Fauna and Flora. Retrieved July 4, 2021, from UNTC:

https: //treaties.un.org/pages/showDetails.aspx?objid=0800000
280105383

[65] UNESCO. (1970). The 1970 Convention . Retrieved July 4, 2021, $\quad$ from
UNESCO: 